\title{
Europeanization of social partnership in EU-acceding Countries
}

\author{
Elena A Iankova**
}

With the advancement of the eastern enlargement of the EU, some advocates of the European social model saw enlargement as the "Trojan horse" against Europeanization, for the Americanization of Europe. In response, the EU recommended the strengthening of social partnership among business, labor and the state in candidate countries. This paper reveals four major venues for change: (1) emphasis on a new philosophy of social dialogue as social governance; (2) broadening the scope of participants in social dialogue; (3) development of autonomous and multi-level social dialogue among the organizations of employees and employers; and (4) capacity building for participation of the social partners in EU-level social dialogue.

Mit der voranschreitenden Ost-Erweiterung der EU sahen einige Verfechter des europäischen Sozialmodels die europäischen Erweiterung als „Trojanisches Pferd" gegen die Europäisierung und für die Amerikanisierung Europas. Als Antwort empfahlen die EU die Stärkung der sozialen Partnerschaft zwischen den Betrieben, den Arbeitskräften und dem Staat in den Kandidatenländern. Dieser Beitrag zeigt vier bedeutende Arten von Veränderungen: (1) die Betonung einer neuen Philosophie des sozialen Dialoges als soziale Governance; (2) die Erweiterung der Teilnehmer im sozialem Dialog; (3) die Entwicklung von autonomen und mehrstufigen Sozialen Dialogen zwischen den Organisationen von Arbeitsnehmern und Arbeitsgebern; und (4) die Entwicklung der Aufnahmefähigkeit für die Beteiligung der Sozialpartner am Sozialen Dialog auf Ebene der EU.

Key words: social partnership; social dialogue; Eastern enlargement of the European Union

* Manuscript received: 22.08.06, accepted: 29.05.07 (1 revision)

** Elena A. Iankova, Lecturer, Johnson Graduate School of Management, Cornell Unniversity. Main research areas: Business, government and civil society relations, international political risk management and business in transition economies. Corresponding address: eail@cornell.edu. 


\section{The European social model, varieties of capitalism and EU enlargement}

Central to the debate on Europe's integration is the clash between conflicting notions of state and individual, or of the role to be played by regulation and by the market. An interpretive framework that gives the relationship between the state and socio-economic interests a central place has distinguished three major variants of contemporary capitalism: corporatism as practiced in most of Western Europe; Anglo-Saxon style neoliberalism, and Japanese statism (Katzenstein 1978; Hart 1992; Esping-Andersen 1990). ${ }^{1}$ That widely used typology of capitalist variants underscores how governments, labor, and business are linked differently and can have varying roles in state governance and market processes, with labor marginalized and the state playing only an indirect part in the neo-liberal United States, governments actively engineering economic development in Asia, and strong interventionist states incorporating policy inputs from labor and business in most of western Europe.

Based on this typology, a distinct, continental European "Social Model" has been discussed for decades, in contrast mainly to the Anglo-Saxon neo-liberal model of privatization, liberalization and globalization, where the market is an end itself. The European social model is thus rooted in the view that markets are always socially and politically embedded; it envisages economic success as being built on deep social foundations. It is a vision of society that implies full employment, good quality jobs, equal opportunities, social protection for all, social inclusion, and involving citizens in the decisions that affect them. The EU's official point of view of the European social model reflects the following common principles: Europe's success must not exclude anyone; solidarity is linked to economic success; there is neither dilemma nor a contradiction between economic and social progress; and the welfare state is not a luxury, a product of economic development, but a factor of production.

Under the European social model, companies are seen as social entities and political bargaining between the interest groups of capital and labor is accepted. Social partnership, collective bargaining and workers' protection are seen as crucial factors in promoting innovation, productivity and competitiveness. Social dialogues among employers, unions, and governments at the European level — though much criticized — have scored some real chievements. Millions of

1 The work of David Soskice incorporates these variables into a broader typology of political economies. He distinguishes two main types of political economy, which he refers to as "coordinated market economies" (CMEs) and "liberal market economies" (LMEs). CMEs include the Scandinavian countries, along with much of continental Europe (though Italy and France are, according to him, somewhat anomalous). LMEs comprise mostly the Anglo-Saxon economies (the United Kingdom, the United States, Canada, New Zealand, and Australia). See in Soskice (1999) and Hall and Soskice (2001). 
EU citizens are benefiting from expanded parental leave and improved rights for part-time workers as a result of agreements negotiated between the Union of Industrial and Employers' Confederations in Europe (UNICE), the Euro-level organization representing European employers, and the European Trade Union Confederation (ETUC).

However, with the rise of neo-liberalism since the 1980s and the decline of Keynesian economic policies - the backbone of the European social modelWestern Europeans found that government money was no longer available for traditional welfare policies, and their leaders engaged in serious debates over the future of the highly praised, consensus-based European social model. The challenge to the European social model is seen as coming from both its own inability to respond to current problems, as well as from international pressures such as globalization but also the eastward enlargement of the EU.

Some experts have even questioned as to whether the European social model really exists or remains just a highly declarative construct (Streeck 1994; Wickham 2001). They have, on the one hand, seen a great diversity and multiplicity of social models in member states, and, on the other, have seriously questioned the ability of Europe's present social model to tackle the modern challenges of globalization. They have argued that social dialogue - which should be the engine of European social integration - has remained meager, in spite of some achievements on part-time work and parental leave. They have further argued that this model has left Europe with gigantic problems: an insurmountable public debt, a rapidly ageing population, 19 million unemployed, and an overall youth unemployment of 18 percent (De Vlieghere/Vreymans 2006; Anderson 1997). Europe's present social model is further seen as unsustainable because keeping the system in place would jeopardize the next generation's future with an unbearable and uncompressible tax burden, and would seriously add to the risk of a total collapse of Europe.

At the same time with the advancement of the eastern enlargement of the EU in the early 2000s, some experts and advocates of the European social model began labeling enlargement as the "Trojan horse" against Europeanization, for the Americanization of Europe (Meardi 2002). According to them the idea of the European social model would be seriously challenged after enlargement because the Central and Eastern European (CEE) candidate countries had developed more liberal regimes in the course of their post-communist transformation, and were practicing a rather different brand of social partnership.

It is true that, starting from the early $1990 \mathrm{~s}$, the post-communist region experienced a boom of social dialogues. After the 1989 breakthrough, there was a broad social consensus that the society at large should move away from oneaparty rule, central economic planning, and a central focus on egalitarianism, and should build a new order based on democracy, the rule of law, and a market economy, with a readiness to accept greater social inequality as part of the price 
for economic prosperity. The transition plan worked out by "tripartite coordination," with government, labor, and emerging business interests as the three main voices in a system of compromise that was, in broad terms, to preserve social peace by distributing the burden and pain of transformation across the population as fairly as possible, with successful political and economic restructuring the anticipated award. The institutional legacies of the past determined some path-dependent variation in the scope and compositions of the tripartite conciliation bodies that emerged across the region (Stark 1992). More importantly, however, tripartite collaboration in one form or another has appeared in all of the post-communist countries, whether economically devastated or economically struggling but sound, left-wing or right-wing in government, or having strong or weak civil societies (Thirkell/Tseneva 1992; Hausner et al. 1993; Hethy 1994; Hethy/Kyloh 1995).

The tripartite forums for social dialogue in the post-communist region have prompted a confusing variety of interpretations - from west-European corporatism to pure neo-liberal pluralism to neo-statism, with multifarious mixtures in between (Iankova 2002:6-7). The confusing variety of analytical interpretations reflected, on the one hand, the underdeveloped and immature corporatist nature of the tripartite arrangements that spread so rapidly across the CEE region in the early 1990s, and on the other - their rather inefficient concrete policy outcomes in terms of the traditional issues of employment, wages, social benefits and income distribution. Ironically, in the conditions of economic crisis and difficult economic restructuring, the social partners often did not negotiate real wage and income increases but mutually acceptable, reasonable drops in living standards. Nevertheless, post-communist social partnership played a particularly important role as a social peace mechanism, as a means to more fairly distribute the social burden of restructuring across the population.

However, because of this highly transitional nature of CEE social partnership, on many issues (privatization, pension systems, taxation, working time, the welfare state, wage differentials and so on), post-communist countries were found to be following a "North American" road rather than that of the European social market economy. The Anglo-Saxon neo-liberal processes had sometimes been explained by the pressures of western lending agencies such as the IMF and the World Bank (Pollert 1999) but, as Meardi argues, these pressures cannot explain the "excess of zeal" in CEE - post-communist countries had been even more keen on deregulating and privatizing than suggested by those agencies. Thus not only the EU but even the World Bank had criticized the Polish healthcare reform for being too market oriented; Polish monetary policy had been criticized by the IMF in April 2001 for being too restrictive, not too generous. In 
spite of the fact that the CEE candidate countries ${ }^{2}$ have signed the Social Charter of the Council of Europe, their actual policies are seen as increasing western fears of Eastern Europe as a "Trojan horse" of deregulation (Meardi 2002:79$80)$.

With central and eastern Europe's accession to the EU, fears of social dumping also emerged on the left, especially among trade union activists. These fears were rooted in the candidate countries' relatively low income level, with wages that, although rising, are still far below the EU average. In Slovenia, for example, the richest applicant, the average wage in the late 1990s was only $40 \%$ of that of its neighbor Austria. On taking over the EU chair in June 1998, Viktor Klima, chancellor of Austria, talked of the need for eastward enlargement, but he also called for long transition periods to help the EU adapt to low-wage competition from the east. Some western European politicians were calling for a delay of 15-20 years before east Europeans win the right to free movement within the Union. This attitude reflected fears that east Europeans would flood the West to take local jobs, despite the fact that when the EU has taken in poor countries before, labor mobility has remained low.

Based on such concerns, the EU aimed at making the social policies in the applicant countries compatible with the European social model, thus hoping to avoid the risk of social dumping. In the course of accession negotiations, the Commission included, among others, special requirements and recommendations for the strengthening of the forms of negotiations among the social partners in candidate countries. This paper reveals the nature of these recommendations, and analyzes the level of their applicability in accession countries, on the example of the Bulgarian experience and secondary research and literature review on the $\mathrm{CEE}$ region as a whole. The Bulgarian data comprises about 40 interviews conducted in the period 2004-2006 with national government officials and experts, members of parliament, local government officials and experts, leaders of national and local business associations, representatives of labor unions and other non-governmental organizations, and professionals from the academic circles in Bulgaria. The analysis is also based on the findings of a national representative survey on the Bulgarian businesses' preparedness for EU membership, conducted in October 2004 by the MBMD Institute for Marketing and Social Research.

A major finding of the paper is that the existing tripartite structures in Bulgaria were largely reshaped in order to comply with the EU requirements in regard to social dialogue. Having in mind that the latter were uniform for all candidate countries and were a pre-condition for EU entry, one could assume that the EU

2 This paper uses the term "CEE candidate countries" instead of "new member states of the EU" to refer to processes that were taking place in the course of accession adjustments and preparations. 
acquis and the accession process in general have harmonized social dialogues across the new EU member states. While additional research and empirical data are necessary to firmly argue for both a convergence and sustainability of social dialogues across CEE after accession, the goal of this paper is to address another issue: to what extent have the "revised" structures of social dialogue in CEE candidate countries acquired a new quality to be part of the deepening integrative processes in Europe? Were special recommendations for changes in the existing social partnership structures necessary in the first place? The concluding section of the paper addresses the issue about the extent to which the new institutions of social dialogues are able to contribute towards the sustainability of the European social model in an era of increased neo-liberal pressures.

\section{The EU recommendations on social dialogue in acceding countries}

Back in 1993, with the formulation of the Copenhagen criteria for entry, the EU did not specifically raise any requirements in terms of social dialogue. After Agenda 2000 was adopted in 1997, the European Commission, aided by the European Economic and Social Committee, included an additional requirement towards the acceding countries for the development of social dialogue and the strengthening of the role of their social partners in the preparation for accession. This requirement became a basic element in the Commission's recommendations and annual regular reports towards the candidate countries.

In regard to Bulgaria's experience, social dialogue emerged in 1990 as an arrangement between the government and the organizations of unions and employers aimed predominantly at preserving social peace during the hard times of post-communist transformation. The National Council for Tripartite Cooperation was strengthened with the 1993 amendments in the Labor Code, which made regular talks among the social partners mandatory. With the preparation of the first position on Bulgaria's candidacy for EU membership in 1997 the Commission emphasized the necessity of encouraging social dialogue in the country, especially in the processes of ownership restructuring, but without providing concrete guidelines about the way and forms of how to conduct and practice social dialogue. In its first regular report in 1998 the Commission emphasized as a weakness of social partnership its restriction only to the tripartite cooperation with weak structures for bipartite negotiations between labor unions and the employer associations. In the Accession Partnership and the respective First National Plan of Bulgaria for the Adoption of the Achievements of the EU Law in 1999 (which determines the priority areas in the process of legal harmonization), the strengthening of social dialogue was defined as one of the short-term objectives, to be accomplished by 2000 .

Overall, the initial formulations in terms of social dialogue were very broad and unspecified. Acceding countries were to pay "necessary attention" to social 
negotiations and social dialogue, and their social partners had to be "sufficiently developed" in order to take their responsibilities at the domestic and European levels over the implementation of the European common law (European Commission and DG Enlargement, 2002). The vagueness was largely due to the fact that the EU has no official definition about the concrete content of social dialogue in member states, it is subordinated to their national specifics and varies widely across them. A broad direction what to change was given but no guidelines were provided on exactly how to change it; it was left to the candidate countries to choose among a menu of institutional solutions about the way and forms of how to conduct and practice social dialogue (Jacoby 2002). Moreover, the Commission did not elaborate any intervening measures and control mechanisms over the effective implementation of its recommendations in terms of social dialogue.

Gradually in the course of accession, however, the social partners in acceding countries faced and dealt with four major venues for change in their social dialogue institutions: (1) emphasis on a new philosophy of social dialogue as social governance rather than a more narrow "social peace" and interest intermediation mechanism; (2) broadening the scope of participants in social dialogue, development of social dialogue beyond the existing tripartite structures, as a broader civic engagement; (3) development of autonomous and multi-level social dialogue among the organizations of employees and employers, without the participation of the state, and especially in regard to the lower sectoral and regional levels; and (4) development of the capacity of the social partners to participate in social dialogue at the European level. The uniformity in addressing the restructuring of the social dialogue institutions was largely stemming from the EU general guidelines on social dialogue.

\section{Social dialogue as shared social governance}

Social dialogue has always been a central element of the European social model, one which has accompanied European integration from the very beginning. Thus the Treaty of Rome in 1957 set up the institution of social dialogue or social partnership between the Commission and the social partners - the organizations of employees and employers, as a continuous interaction between them with the aim of reaching agreement on the control of certain economic and social variables.

Social dialogue was strengthened in the 1970s, and a new era was established in the late 1980s and early 1990s. The Single European Act, ratified in 1987, gave the European Commission the responsibility of promoting dialogue between the social partners. The goal was to reach a common position on employee issues, especially for the development of European-level collective bargaining (Springer 1992). The Charter of Fundamental Social Rights of Workers, more popularly known as the Social Charter, was adopted in December 1989 by 
eleven of the then twelve member states, with Britain refusing to sign it. The Charter proposed 26 fundamental social rights, among which were workers' right to free movement; fair remuneration; approximation of work practices, particularly for part-time and temporary workers; adequate social security benefits; free association and collective action, subject to national agreements; access to vocational training; equal opportunities for women and men; and "appropriate" forms of consultation and participation in corporate decisionmaking. The Treaty on European Union (1992) adopted the Social Charter as the 14th Protocol to the Treaty, including an agreement on Social Policy. The Social Protocol set out a mechanism whereby management and labor representatives could negotiate work-related deals. They could then ask the countries collectively to endorse the agreements, sometimes through legislation. Individual countries have no powers to amend legislation proposed by the social partners - they must either accept it in full or reject it.

The Amsterdam Treaty of June 1997, which revised the Treaties on which the EU is founded, incorporated the Social Charter. In May 1998 the European Commission adopted a Communication on adapting and promoting social dialogue in the context of strengthening social policy. The document outlined a number of measures designed to introduce more effective and open social dialogue, establishing mechanisms for the exchange of information and replacing existing structures with more flexible forums for dialogue. Most importantly, with the entry into force of the Amsterdam Treaty social dialogue became a means of transposing Community directives at national level. As stipulated in the Treaty, a lot of Community directives may be implemented in the member states by means of either legal harmonization or agreements between the social partners. As a result, the social partners in the EU have become key actors in what some experts define as "shared social governance" (Vaughan-Whitehead 1999:2). As the EU common policies reduce the capacity of member states for independent action, social dialogue has again become an important mechanism for national policy makers to seek the consent of social partners to avoid being blamed for unpopular decisions. The general revival of social partnership in western Europe in the early 1990s was largely due to the restructuring pressures in preparation for membership in the Economic and Monetary Union (Grote/Schmitter 1999).

In the process of enlargement and accession negotiations the Commission actively promoted this new understanding of social dialogue not so much as a means for mediation and conciliation but as a new form of policy making, as a collaborative governance mechanism. Overall, the message from Brussels was for the encouragement of the cooperation between the social partners in order to be able to participate in the self-regulation of the integrated European market and the achievement of greater competitiveness of the national economies. However, the implementation of Community legislation through agreements 
between the social partners rather than national legislation requires strong social dialogue and collective bargaining structures, and representative employer and employee organizations to ensure the effective implementation of national agreements at lower levels. The lack of these conditions in candidate countries predetermined the transposition of EU common law through national legislation rather than through agreements between the social partners. None of the new EU member states or still candidate countries has used the option of national agreements between the social partners for the transposition of EC legislation (Vaughan-Whitehead 2003:237).

\section{Participation in accession negotiations}

Despite of this drawback, the EU used another tool for the strengthening of the institution of social dialogue in EU accession countries and converting it into a shared social governance mechanism. It encouraged the active engagement of the social partners in consultations over the harmonization of domestic legislation with the EU common law. There was a belief that the participation of the social partners in the accession process would help at a later stage for the effective implementation of the European common law, the acquis communautaire, at firm, branch and regional levels. The necessity for active participation of the social partners in accession negotiations also stemmed from the fact that many EU directives specify such involvement of the social partners at national level, especially those directives that are focused on health and safety issues in the EU (Lado/Vaughan-Whitehead 2003:78).

As a result, a special institutional structure was created for the inclusion of the social partners in accession negotiations. Thus 31 working groups were established on the basis of the sections of EU common law which formed the basis of accession negotiations. The working groups comprised representatives not only of the state ministries but also of the social partners, civil society and political institutions. The working groups formed the extended negotiation team of each candidate country and had the tasks to prepare draft negotiation positions on a sector-by-sector basis, as well as general positions on the conformity of draft laws with the acquis, and on the national priorities and order of translation of the EU normative acts in the respective industry/sector. The social partners had the right to participate in these working groups - to be informed about the course of negotiations, as well as to be consulted on issues of their competence.

For Bulgaria in particular, the most active participation of the social partners was in the two working groups coordinated by the Ministry of Labor and Social Policy - free movement of people, and social policy and employment. In these groups, all representatives of the social partners (the CITUB, Podkrepa CL, the Bulgarian Industrial Association, the Bulgarian Chamber of Commerce and Industry, the Union of Employers in Bulgaria, the Association of Industrial Capital in Bulgaria, the Union of Private Economic Enterprise, and the 
Vazrazhdane Union of Private Producers) and a variety of NGOs were represented and consulted at all stages of the preparatory work. In addition, participation of labor unions was assessed as particularly useful in the working groups on regional policy and coordination of the structural instruments; protection of consumers and their health; tax policy; agriculture; statistics; and the environment (Ribarova 2001:105). Representatives of the business community were more actively involved in the elaboration of the government position papers on the economic chapters of the acquis, especially the chapter about the free movement of goods (interview data).

Overall, the Bulgarian government claimed that its positions in the accession negotiations with the EU were all written with the participation of civil society (interview data). However, problems arose from the fact that once the negotiation position was agreed upon in the working groups, the state bureaucrats could negotiate something different during the actual negotiations with the EU representatives. A common and wide-spread accusation on the business side was that because of that, there was no transparency on the negotiation process with the EU (Gelovska 2004). Besides, participation in the working groups allegedly did not lead to the strengthening of the social partners - many complained that their participation was formal and meaningless. They felt they were still lacking the expert capacity in order to be legislators and political consultants (interview data; Atanassova 2004).

\section{Joint consultative committees on economic and social issues}

The establishment of joint consultative committees on economic and social issues between the EU and each candidate country was another attempt at fostering the new philosophy of social dialogue as shared social governance. The EU - Bulgaria Joint Consultative Committee was established in January 1999. The Bulgarian part of the Committee comprised three groups: employers (the Bulgarian Industrial Association); trade unions (CITUB and Podkrepa CL); and various interests (the Federation of Consumers in Bulgaria; the Bulgarian Women's Union; and a farmers' Federation of the Cooperatives in Bulgaria). The EU part of the Consultative Committee also comprised three groups: employers (the Assembly of French Chambers of Commerce and Industry, ACFCI; the General Italian Confederation of Commerce, Tourism, and Services, Confcommercio; and the Confederation of Finnish Industry and Employers); employees (the Netherlands Trade Union Confederation, FNV, and the French Democratic Confederation of Labor, CFDT); and various interests (the Greek Economic Chamber, and the Central Union of Agricultural Producers and Forest Owners MTK, Finland).

The committees were set up to pave the way for enlargement of the EU by promoting dialogue and supporting the professional organizations in acceding countries in their efforts to create a functioning civil society, one in which their consultation by the government would be an integral part of the decision-making 
process. Another task of the joint consultative committees was to promote dialogue and cooperation between the economic and social interest groups in the European Union and those in acceding countries. The dialogue covers all economic and social aspects of the relations between the EU and acceding countries in light of the Association/Europe Agreements and the Accession Partnership Agreements between the EU and each of them. However, as with the participation in the 31 working groups, the social partners complained of lack of meaningful participation in the joint consultative committees.

\section{Joint management of the structural funds and the cohesion fund of the EU}

Overall, the need to include the social partners in the management of the EU structural funds (especially the European Social Fund) and the cohesion fund is seen as an important milestone in securing their capacity to participate in social dialogue as a meaningful mechanism of shared social governance.

Thus in regard to the utilization of pre-accession funds from the SAPARD Program (for agricultural restructuring and the development of rural regions), a special Monitoring Committee on the Implementation of SAPARD Program was created in Bulgaria. The Committee comprised 32 members from the national government bureaucracy and local governance structures, the business community (the Bulgarian Chamber of Commerce and Industry, the Bulgarian Industrial Association), labor unions (Federation of Independent Trade Unions in Agriculture at the CITUB; Federation "Land" at Podkrepa CL), and nongovernmental organizations in the area of environmental protection. The Monitoring Committee reviewed the achieved progress in the fulfillment of the goals of the Program, and approved amendments in the physical and financial indicators of the system for monitoring and assessment, created at the SAPARD Agency. It also approved criteria for assessment and selection of projects to be financed under each measure of the Program, before their transfer to the Delegation of the European Commission in Bulgaria for approval.

Furthermore, the partnership principle is at the heart of the design and use of post-accession financial instruments. It implies close cooperation between the European Commission, central and sub-national governments, NGOs and the private sector, in order to achieve common development objectives. In particular, public-private partnerships are seen as building social capital, attracting the co-financing needed to utilize the structural funds, and facilitating the absorption and modernization policy processes at the national and subnational levels.

For example, the Strategy for the Participation of the Republic of Bulgaria in the Structural Funds and the Cohesion Fund of the EU, developed in 2002, is based on several principles which have to be applied in all activities related to the programming, execution and monitoring of activities financed from the structural funds and the cohesion fund of the EU. The principle of partnership 
between the public and the private sector is one of them. A public-private partnership is most often formed for the purpose of delivering a project or service traditionally provided by the public sector. Through this agreement, the skills and assets of each sector (public and private) are shared in delivering a service or facility for the use of the general public.

\section{Social dialogue as a civic engagement}

In the course of its eastern enlargement the EU insisted on the broadening of the scope of participants in social dialogue, for the inclusion not only of the organizations of employers and employees but also all other formations that have economic or social role. In that regard, an accession requirement was added for the creation of permanent economic and social councils in each candidate country before accession. The idea was to transform the existing forms of tripartism at the national level into broader forms of civic dialogue, including in addition to the social partners (employers and labor unions) other interests from the third sector, and at the same time to provide to the social partners a separate arena for negotiations without the participation of the state, in the form of so called bipartite or autonomous social dialogue.

Economic and social councils were created in each accession country. They have been modeled on the European Economic and Social Council, as consultative organs representing the views of civil society on the economic and social development of an acceding country. The councils are structured into three groups - employers, employees, and various interests. Their task is to develop opinions on: (i) draft laws, national programs and plans regarding the economic and social development of the country; (ii) legal acts of the national parliaments regarding issues of economic and social development; (iii) strategic problems of the government's economic and social policy; and (iv) annual memorandums and analyses of economic and social development of the country.

The Bulgarian parliament adopted the Law on the Economic and Social Council in 2001, and amended it in 2003. The Council aims to establish itself as the voice of Bulgarian organized civil society and to take an active part in the process of integration of the country into the EU. Three major state institutions address the Council, seeking its opinions - the Presidency; the National Assembly; and primarily the Ministry of Labor and Social Policy from the government side. However, as government institutions are not directly involved in the activities of the Council, its purely consultative status is seen by business and labor as a disadvantage that reduces the overall public impact of its opinions. According to some business representatives, the Council's opinions are met by the government institutions just as opinions and nothing more, there is no direct impact on the government policy making process. Besides, the Council opinions avoid contentious issues where conflicts of interests exist between employers and labor unions, so that the Council members would be 
able to take decisions with a qualified majority vote. The contentious issues are resolved by other means and through other channels.

Overall, in all acceding countries with the exception of Bulgaria the existing tripartite institutions have been transformed into economic and social councils, while in Bulgaria the tripartite commission continues to function separately from the Economic and Social Council. There is an understanding in Bulgaria that the tripartite commission should not cease to exist because the problems of capital and labor need constant and separate negotiations with the state involved in them. The Economic and Social Council does not negotiate and does not reach agreements with the government, while the tripartite commission negotiates with the government on a variety of issues related to the employment relationship, living standards and incomes of the population. Another difference that was preserved between the two institutions is that the Economic and Social Council gives opinions on crucial aspects and problems of economic and social development, while the tripartite commission discusses not so general, strategic issues, but many day-to-day issues.

\section{Autonomous and multi-level social dialogue}

The European institutions and European social partners further emphasized that the development of autonomous, bipartite social dialogue (without the participation of the state) in the acceding countries, as well as the real capacity of the social partners to develop it, is an integral part of the EU acquis communautaire. That was in sharp contrast to the existing practices in candidate countries, all of which - with the exception of Slovenia - did not have a tradition of national (central) bilateral bargaining between the social partners but had developed in the course of transition and transformation tripartite institutions for social partnership, with the active participation of the state.

The EC has always been critical of the existing tripartite structures, for not being very effective in determining the final policy outcomes (European Commission 2002). However, the role of the state in social partnership remained a leading one instead of regulative, because of the specifics of transition (Iankova/Turner 2004). Tripartite relations may remain a permanent feature of policy-making in the new and future member states for the foreseeable future (VaughanWhitehead 2003:236).

Social partnership has survived all political changes in the process of postcommunist transition and transformation, and the institution of tripartism has remained in place. The creation of an independent, autonomous social dialogue when the labor unions do not have the capacity and the business organizations do not have the desire to negotiate with them, proved to be a difficult task. Most of the social partners in candidate countries felt that their specific structures of social dialogue reflect the reality of industrial relations in their countries, and should not be modified just because they would not suit the structures of social 
dialogue that take place in Brussels (Lado/Vaughan-Whitehead 2003:83). That was one of the reasons for the preservation of the Bulgarian National Council for Tripartite Cooperation.

Furthermore, in most of the accession countries social dialogue had been predominantly developed at the central, national level, with very weak lower levels of bargaining. The weakness of sectoral structures of social dialogue runs against the strengthened role of social partners in sectoral dialogue committees at the EU level, where the EU social partners conclude framework agreements, many of which are then converted into EC directives which thus become binding for all EU enterprises in those sectors. Regional social dialogue is also very important for redistributive processes related to European structural funds. That is why the EC emphasized in the enlargement process that strong sectoral and regional structures of social dialogue have to be developed in the accession countries, with strong social partners at these levels.

The amendments in the Bulgarian Labor Code in March 2001 created the conditions for the establishment of the EU standards in social dialogue at the sectoral, branch and regional levels. The lack of duration of collective agreements was abolished. Only the representative organizations of employees and employers were defined as parties in the collective agreement for a sector or a branch, thus excluding state participation. At the regional level, these two parties also conclude collective agreements for activities financed by municipal budgets. The bipartite sectoral, branch and regional councils for social partnership have to discuss and issue opinions on the various aspects of industrial relations, social security, and living standards. As a result of the intensified social dialogue in 2002, new agreements have been concluded in different sectors and branches of the Bulgarian economy -8 at the sectoral level, 32 at the branch level, and 12 new agreements at the level of national agencies and companies (Mihailova 2004:85). Overall, the collective agreements concluded in Bulgaria after 2001 seem to be of a new type, in compliance with the EU requirements as stipulated in the Bulgarian labor code.

This direction for change in the social dialogue institution proved to be a very difficult one, first, because the institutional weakness of the social partners is especially acute at sectoral level. In most accession countries employers' organizations are either not organized, or not authorized to conclude binding agreements at this level. Some sectoral agreements, when analyzed in detail, would not even qualify as such under the common understanding of the term. This is either because they are simply company agreements with a national scope (such as most agreements in the railways, postal service, telecommunications, energy supply, oil supply, etc.), or because they are just multi-employer agreements, signed by a group of individual enterprises and the relevant trade union federation. Second, the changing nature of employment policies and practices under the slogan of flexibility and competitiveness is 
mostly manifested at the lower sectoral and regional levels, which also contributes to the structural weakness of social dialogue at lower levels.

As a result, it seems that the vast majority of workers in the accession countries are not covered by collective agreements. Thus in 2002 the average bargaining coverage rate for the accession countries was estimated at $25-30 \%$ of the labor force. This contrasts with the general trend in the EU-15, where in 2000-2002 the coverage rates were as high as $100 \%$ in Belgium and Austria, above $90 \%$ in Sweden, Finland and France, and covered more than two-thirds of employees in Denmark, Spain, Netherlands, and Germany (Lado/Vaughan-Whitehead 2003:72-73).

\section{Capacity to participate in European-Level social dialogue}

Integration is profoundly changing the relationship between the state and organized interests in applicant countries. Interest organizations no longer look at their national governments as the sole source of economic and social policy; governments share this function with the EU's policy-making institutions. Because of that, the social partners in acceding countries have to assume many new responsibilities related to their effective participation in European bodies of social dialogue. Involvement in EU-level social dialogue would give them an opportunity to discuss their problems in a wider context, and contribute to the design of appropriate European policies in the long run. It may also help them face the new difficulties that may emerge with the prospect of EU enlargement, such as risks of social dumping for the west, or brain-drain for the east, which the social partners from neither the candidate countries nor the EU member states would be able to tackle alone.

Hence a multi-dimensional approach is emerging as a major change of social dialogue. The social partners have to learn how to operate at multiple levels of governance, and how to incorporate the European context even when dealing with very specific micro issues at the local level. They must thus also consider not only traditional areas of collective bargaining but also other social and economic elements of European integration, while becoming an integral part of the respective EU policy networks.

Building capacity to participate in EU-level social dialogue is a rather difficult task, having in mind that most of the social partners in candidate countries are involved in internal restructuring, facing financial difficulties while struggling with a lack of human and financial resources, and exerting themselves at the domestic level to protect the interests of their members on domestic issues, such as wages and employment, which have often been threatened in the transition process. Because of that, membership in European interest organizations, broad interaction with the respective counterparts from EU member states, and participation in European-level structures became an important learning component for the social partners in accession countries. 
The EU institutions and social partners organized a series of initiatives to help their counterparts in acceding countries prepare for such participation. As a first step, within the PHARE's Democracy Program, the "Social Dialogue" Project ran until 1998 and had as its major goal the strengthening of the organizational capacity of the social partners and educating them in social dialogue and negotiations as an alternative to spontaneous strike actions in the emerging market environment. Expert assistance and office equipment were provided to the social partners under this program.

In order to promote social dialogue across applicant countries, arrangements were made for representatives of the social partners and governments in both western and eastern Europe to visit one another. Such trips, which involved briefing sessions beforehand and group learning sessions afterward, were aimed at giving CEE social partners concentrated exposure to other countries' approaches to equivalent work. A series of policy seminars was organized under the "Social Dialogue" Project. Different courses were set up at different levels, covering the major areas of skills the social partners needed, such as the structure of the market economy and industrial relations, labor and social welfare legislation, privatization and employment contracts, negotiation skills, development of a local economy, employer and trade union structures and organizations, conflict management, and general technical skills for use at the base organization. The Project aimed also at strengthening and professionalizing the structures of the social partners in order to ensure the adequate functioning of social dialogue; developing an arbitration and conciliation service and strengthening the structures and processes of the industrial court; and establishing an information and resource base to meet the social partners' needs.

Furthermore, the Economic and Social Committee of the EU organized meetings and hearings in Brussels, Warsaw, Tallinn, and elsewhere to enable applicant countries' social and economic organizations to voice their opinions. It organized a major conference that brought together 93 social partner representatives from the EU and 80 from the applicant countries in March 1999 to discuss the social partners' role in the enlargement process (European Report 1999). The conference emphasized the importance of developing social dialogue structures and activities in the applicant countries so that they can take part in the various social dialogue structures at the European level, which play a triple role: developing joint actions between workers' and employers' representatives, negotiating framework agreements, and assisting the EU institutions in their areas of responsibility.

In addition to the activities of the Economic and Social Committee of the EU, UNICE and ETUC ran a joint project on social dialogue in the new member states. They tried to strengthen employers' and employees' organizations and teach them to be active in EU-level social dialogue. Both UNICE and ETUC sent representatives on missions in the CEE countries, and organized seminars to 
improve awareness of participation in EU-level social dialogue. In November 2002, the national social partners from 30 European countries - including the CEE candidate countries - participated in the work of the Social Dialogue Summit where representatives of ETUC, UNICE/UEAPME and CEEP discussed the work program for 2003-2005. The sectoral/branch organizations of the social partners also play an important role in capacity building. Some of the Bulgarian branch associations underwent a process of restructuring and mergers in order to be compatible with the organization structures at the EU level. For example, the Bulgarian chambers of food and textile, metallurgy and chemistry, had to merge in order to facilitate links and contacts with the European-level branch associations.

The communication strategies of the CEE governments also aimed at preparing the different segments of civil society for the need of participation in EU-level governance structures. The major goal of the Communication Strategy of the Bulgarian government was to prepare all professional circles in Bulgaria for successful integration in the EU policies from the very start of Bulgaria's accession; to improve the public knowledge and understanding of the preaccession programs of the EU; and to motivate all partners for a more active participation in the processes of program implementation, monitoring and evaluation. The communication techniques of the strategy included a network of information centers on European problems; publications on the European theme (books, brochures, newspapers, magazines and journals, bulletins and newsletters, the internet); radio and TV broadcasts; and meetings and discussions with representatives of target groups, including the social partners (Bulgarian Government 2002:9).

\section{Conclusions: Social dialogue and prospects for sustainability of the European social model in an enlarging European Union}

Social partners in CEE accession countries have put a lot of effort in changing the social dialogue institutions under the broad recommendations provided by the EU. They have not been equally successful in meeting all the challenges stemming from these recommendations. Thus it seems that the new philosophy of social dialogue as social governance rather than a social peace and conflict resolution mechanism has been well accepted but still difficult to implement in practice. In most accession countries the social partners suffer from lack of effective involvement in policy making while they have an important role to play in the implementation of the acquis.

A very promising development in that regard is the signing in September 2006 of a Pact on Economic and Social Development of Bulgaria in the Period Ending 2009, by Prime Minister Sergei Stanishev and leaders of the nationally representative workers' and employers' organizations. The document outlines the principles under which Bulgaria's social and economic sectors will develop until 
2009. It is an important civil contract which aims at the practical integration of the country into the EU through the achievement of higher competitiveness of the Bulgarian economy, higher economic growth, and higher quality education and health care. Importantly, the pact was the result of eight-months negotiations among the social partners (Banker, No. 39, September 30, 2006).

The social partners have been reluctant in replacing the existing tripartite structures for social dialogue with purely consultative economic and social councils without the participation of the state in them, and with a much broader civil society engagement. Some even saw this new development as the "Trojan horse" against social partnership, because it was allegedly reducing the importance of the social partners vis-à-vis the state to just one among many and competing social and economic interests (interview data from Bulgaria). Perhaps that is why the Bulgarian social partners remained firm in their will to keep the existing national tripartite council parallel to the economic and social council that they had to establish as a pre-condition for EU entry.

The establishment of autonomous, bipartite social dialogue, without the participation of the state, and the development of bipartism at lower sectoral and regional levels also encountered a lot of difficulties in accession countries. However, these difficulties were not so much an issue of social partners' strategic choices but were mainly due to structural weaknesses and factors, such as the institutional weakness of the social partners at lower sectoral and regional levels, and the general trend towards flexibility which is most clearly manifested at these lower levels.

In terms of capacity to participate in European-level social dialogue, a lot has been done by the EU institutions and actors to help their counterparts in accession countries prepare for such participation. The social partners in accession countries have received a lot of financial, expert and logistical assistance, and have improved considerably their understanding of the involvement of economic and social interests in the process of European integration and EU-level policy making. They still need to master their emerging capacity for participation in EU-level social dialogue but in this venue for change the social partners do not have to deal with neither strategic-choice, nor structural difficulties.

Overall, the prospect that the social partners from CEE accession countries will converge or harmonize toward existing European social dialogue standards is unlikely in the foreseeable future. Rather, it appears more likely that the more liberal approach of the new member states will provide a significant additional impetus for the further diversification of the concept of social dialogue in Europe. However, this does not automatically translate into a challenge for the European social model. The latter has already proven to successfully function on the basis of a wide variation in existing social dialogue institutions across EU 
member states, and the prospects for an eastern European "Trojan horse against Europeanization" are highly unlikely.

\section{References}

Anderson, A. (1997): Europe Faces Challenge of 18 M Unemployed, in: European Dialogue, $6,22-23$.

Archer, C./Butler, F. (1996): The European Union: Structure and Process, New York: St. Martin's Press.

Atanasova, G. (2004): Ot tripartizym kym evropejski socialen dialog: problemi i vyzmoznosti, in Bylgaria na praga na Evropejskija syjuz: tristrannoto sytrudnichhestvo i razvitieto na industrialnite otnoshenija. Sravnitelni modeli, Sofia: Institute for Regional and International Studies, 96-141.

Bulgarian Government. (2002): Communication Strategy, Sofia: Government of the Republic of Bulgaria.

De Vlieghere, M./Vreymans, P. (2006): Europe's Ailing Social Model: Facts \& Fairy Tales, in: Work for All www publication.

Esping-Andersen, G. (1990): The Three Worlds of Welfare Capitalism, Princeton, NJ: Princeton University Press.

European Commission. (2002): Industrial Relations in Europe, Brussels: Directorate General for Employment and Social Affairs, September.

European Commission/DG Enlargement. (2002): Enlargement of the European Union. Guide to Negotiations, Chapter by Chapter, on http://europa.eu.int/comm/enlargement/negotiations/chapters/index.htm

European Report. (1999): Padraig Flynn Encourages Development of Social Dialogue, in: European Report, 2393, March 24.

Gelovska, E. (2004): Biznesyt e v nevedenie kakvo se dogovarja s ES, in: Dnevnik, March 16.

Grote, J.R./Schmitter, P.C. (1999): The Renaissance of National Corporatism: Unintended Side-Effect of European Economic and Monetary Union or Calculated Response to the Absence of European Social Policy?, in: Transfer. European Review of Labour and Research, 5, 1-2, 34-63.

Hall, P.A./Soskice, D. (eds.). (2001): Varieties of Capitalism: The Institutional Foundations of Comparative Advantage, Oxford: Oxford University Press.

Hart, J.A. (1992): Rival Capitalists: International Competitiveness in the Unites States, Japan, and Western Europe, Ithaca, NY: Cornell University Press.

Hausner, J./Jessop, B./Nielsen, K. (eds.). (1993): Institutional Frameworks of Market Economies: Scandinavian and Eastern European Perspectives, Aldershot: Avebury.

Hethy, L. (1994): Tripartism in Eastern Europe, in: Hyman, R./Ferner, A. (eds.): New Frontiers in European Industrial Relations, Oxford-Cambridge: Blackwell, 312-36. 
Hethy, L./Kyloh, R. (1995): A Comparative Analysis of Tripartite Consultations and Negotiations in Central and Eastern Europe, in: Kyloh, R. (ed.): Tripartism on Trial: Tripartite Consultations and Negotiations in Central and Eastern Europe, Geneva: ILO-CEET.

Iankova, E.A. (2002): Eastern European Capitalism in the Making, Cambridge and New York: Cambridge University Press.

Iankova, E./Turner, L. (2004): Building the New Europe: Western and Eastern Roads to Social Partnership, in: Industrial Relations Journal, 35, 1 (January), 76-92.

Jacoby, W. (2002): Ordering from the Menu: How Central and East European States Cope with EU Demands for Institutional Reform, Paper presented at the Conference of Europeanists, Chicago.

Katzenstein, P.J. (1984): Corporatism and Change: Austria, Switzerland and the Politics of Industry, Ithaca, NY: Cornell University Press.

Katzenstein, P.J. (1985): Small States in World Markets: Industrial Policy in Europe, Ithaca and London: Cornell University Press.

Lado, M. (2002): EU Enlargement: Reshaping European and National Industrial Relations?, in: The International Journal of Comparative Labour Law and Industrial Relations, 18: 101-124.

Lado, M./Vaughan-Whitehead, D. (2003): Social Dialogue in Candidate Countries: What For?, in: Transfer, 1: 64-87.

Meardi, G. (2002): The Trojan Horse for the Americanization of Europe? Polish Industrial Relations Towards the EU, in: European Journal of Industrial Relations, 8, 1, 77-99.

Mihailova, T. (2004): Socialno partnjorstvo i socialen dialog v stranite ot centralna i iztochna Evropa - kandidatki za Evropejskija syjuz, in: Bylgaria na praga na Evropejskija syjuz: tristrannoto sytrudnichhestvo $\mathrm{i}$ razvitieto na industrialnite otnoshenija. Sravnitelni modeli, Sofia: Institute for Regional and International Studies, 51-95.

Pollert, A. (1999): Transformation at Work, London: Sage.

Soskice, D. (1999): Divergent Production Regimes: Coordinated and Uncoordinated Market Economies in the 1980s and 1990s, in: Kitschelt, H./Lange, P./Marks, G./Stephens, J.D. (eds.): Continuity and Change in Contemporary Capitalism. New York: Cambridge University Press, 101-134.

Springer, B. (1992): The Social Dimension of 1992: Europe Faces a New EC, Praeger.

Stark, D. (1992): Path Dependence and Privatization Strategies in East Central Europe, in: East European Politics and Societies, 6, 1 (Winter), 17-54.

Streeck, W. (1994): European Social Policy After Maastricht: The 'Social Dialogue' and 'Subsidiarity,' in: Economic and Industrial Democracy, 15, 2, 151-77.

Thirkell, J.E.M.,/Tseneva, E.A. (1992): Bulgarian Labour Relations in Transition: Tripartism and Collective Bargaining, in: International Labour Review 131, 3, 355-66.

Vaughan-Whitehead, D.C. (2003): European Union Enlargement Versus Social Europe? The Uncertain Future of the European Social Model, Edward Elgar.

Vaughan-Whitehead, D. (1999): Social Dialogue in EU Enlargement: Acquis and Responsibilties, Mimeo. 
Wickham, J. (2001): The End of the European Social Model: Before It Began?, in: EurUnion www publication. 